\title{
Arsenic Measurement
}

National Cancer Institute

\section{Source}

National Cancer Institute. Arsenic Measurement. NCI Thesaurus. Code C147305.

The determination of the amount of arsenic present in a sample. 